\title{
HUBUNGAN KOMUNIKASI MASSA PEMERINTAHAN MELALUI RADIO DESA TERHADAP PARTISIPASI MASYARAKAT DALAM KEGIATAN DESA \\ (Studi Radio Desa di Desa Sempu Kecamatan Sempu Banyuwangi)
}

\author{
Rofy Meida Syah Putra; Emy Kholifah R, \\ Prodi Ilmu Pemerintahan FISIP Universitas Muhammadiyah Jember \\ emykholifah25@gmail.com
}

Received: 20 Januari 2018, Revised: 1 Februari 2018, Accepted: 21 Februari 2018

\begin{abstract}
Abstrak:
Berdasarkan hasil analisa data dan pembahasan kajian, dapat disimpulkan bahwa Radio Desa yang ada di Desa Sempu memiliki hubungan terhadap partisipasi masyarakat dalam kegiatan desa, hal tersebut disebabkan oleh karena radio desa dipersepsikan positif, baik secara informasikan yang diberikan oleh Radio Desa dan acara yang disuguhkan oleh radio desa sesuai dengan kebutuhan masyarakat dan berdampak pada partisipasi masyarakat desa, sehingga Radio Desa sudah memerankan diri sebagai komunikasi massa, hal tersebut terbukti dari 7 varibel pertanyaan, dan 7 pertanyaan terkait dengan partisipasi masyarakat desa. selanjutnya berdasarkan mayoritas jawaban responden terhadap semua pertanyaan memberikan penjelasan bahwa keberadaan Radio Desa memiliki dampak atau hubungan signifikan terhadap peningkatan partisipasi masyarakat di Desa Sempu. Kata kunci: Komunikasi Massa, Radio Desa, dan Partisipasi Masyarakat
\end{abstract}

\begin{abstract}
:
Based on the results of data analysis and discussion of the study, it can be concluded that the existing Village Radio in Sempu Village has a relationship to the participation of the community in village activities, it is caused by the village radio perceived positively, both informed given by Village Radio and the event presented by village radio in accordance with the needs of the community and have an impact on the participation of village communities, so that Radio Desa has acted as mass communication, as evidenced by 7 questions variables, and 7 questions related to the participation of village communities. then based on the majority of respondents' answers to all questions provide an explanation that the existence of Radio Desa has a significant impact or relationship on increasing community participation in the Village Sempu.
\end{abstract}

Keywords: Mass Communication, Village Radio, and Community Participation 


\section{A. PENDAHULUAN}

\subsection{Latar Belakang}

Dalam kajian ini, penulis meneliti hubungan komunikasi massa pemerintah terhadap partisipasi masyarakat. Komunikasi massa adalah sebuah informasi yang dilakukan melalui media massa.Definisi komunikasi massa yang paling sederhana dikemukakan oleh Bittner (Rakhmat,seperti yang disitir Komala, dalam karnilh, dkk.1999), yakni: komunikasi massa adalah pesan yang dikomunikasikan melalui media massa pada sejumlah besar orang (mass communication is messages communicated through a mass medium to a large number of people). Dari definisi tersebut dapat diketahui bahwa komunikasi massa itu harus menggunakan media massa. Jadi sekalipun komunikasi itu disampaikan kepada khalayak yang banyak, seperti rapat akbar di lapangan luas yang dihadiri oleh ribuan, bahkan puluhan ribu orang, jika tidak menggunakan media massa, maka itu bukan komunikasi massa.

Jadi komunikasi massa pemerintah adalah suatu informasi tentang penyelenggaraan pemerintah, dilakukan dengan media massa bertujuan untuk menyebar luaskan informasi kepada khalayak masyarakat, agar masyarat dapat mengetahui tentang apa penyelenggaraan atau progam progam yang dilakukan pemerintah untuk adanya pembangunan desa. Dengan demikian,media massa merupakan salah satu alat dalam proses komunikasi massa. Karena media massa mampu menjangkau khalayak yang lebih luas dan relatif lebih banyak. Oleh karena itu media massa sangat berpengaruh juga dalam terciptanya komunikasi massa yang transparan dalam segala aspek di kehidupan sehari hari. Komunikasi massa yangdidapatkan dalam kehidupan sehari-hari akan mendorong partisipasi masyarakat.

Partisipasi masyarakat adalah keterlibatan aktif dari masyarakat secara sadar untuk berkontribusi secara sukarela dalam program pembangunan dan terlibat mulai dari perencanaan, pelaksanaan, monitoring sampai pada tahap evaluasi. Partisipasi masyarakat sangat diperlukan untuk adanya pembangunan desa karena masyarakat harus ikut andil dalam kontribusi agar pemerintah desa selalu terbuka dengan masyarakat. Bila masyarakat tidak berkontribusi dalam 
pembangunan desa maka kemungkinan besar pemerintah desa lebih tertutup dengan masyarakat.

Informasi awal yang diperoleh diketahui bahwa kenyataan yang terjadi di lapangan menunjukkan bahwa partisipasi masyarakat di Desa Sempu Kecamatan Sempu Banyuwangikabarnya cukup aktif Dalam Kegiatan Kebersihan,Keamanan dan Keterampilan Masyarakat, di mana masyarakat dapat mengetahui informasi untuk melaksanakan Kegiatan Desa melalui radio desa.

Dari pernyataan di atas menjadi alasan bagi penulis mengambil judul:

Hubungan Komunikasi Massa Pemerintahan Melalui Radio Desa Terhadap Partisipasi Masyarakat Dalam Kegiatan Desa (Studi Radio Desa di Desa Sempu Kecamatan Sempu Banyuwangi).

\subsection{Rumusan Masalah}

Berdasarkan latar belakang masalah yang telah dijelaskan di atas makarumusan masalah dalam kajian ini adalah bagaimana hubungan komunikasi massa melalui radio desa terhadap partisipasi masyarakat dalam kegiatan desa?

\subsection{Tujuan Kajian}

Sedangkan tujuan kajian adalah untuk mengetahui hubungan komunikasi massa melalui radio desa terhadap partisipasi masyarakat dalam kegiatan desa.

\subsection{Metode Kajian}

Metode kajian yang digunakan pendekatan masalah kuantitatif. Di mana dalam kajian ini dilakukan di Desa Sempu Kecamatan Sempu Kabupaten Banyuwangi.

\section{B. TINJAUAN PUSTAKA}

\subsection{Komunikasi Massa}

\subsubsection{Definisi Komunikasi Massa}

Komunikasi Massa adalah bentuk komunikasi yang menggunakan saluran (Media) dalam menghubungkan komunikator dan komunikan secara massal, berjumblah banyak, terpencar, sangat heterogen dan menimbulkan efek tertentu. Selain itu pesan yang disampaikan cenderung terbuka dan mencapai khalayak 
dengan serentak atau komunikasi massa juga bisa diartikan dimana proses organisasi media membuat dan menyebarkan pesan kepada khalayak banyak (publik). Organisasi - organisasi media ini akan menyebarluaskan pesan-pesan yang akan memengaruhi dan mencerminkan kebudayaan suatu masyarakat, lalu informasi ini akan mereka hadirkan serentak pada khalayak luas yang beragam. Hal ini membuat media menjadi bagian dari salah satu institusi yang kuat di masyarakat.Dalam komunikasi massa, media massa menjadi otoritas tunggal yang menyeleksi, memproduksi pesan, dan menyampaikannya pada khalayak.

Komunikasi massa menurut para ahli terdiri dari beberapa macam diantaranya:

1. Definisi komunikasi massa yang paling sederhana dikemukakan oleh Bittner (Rakhmat,seperti yang disitir Komala, dalam karnilh, dkk.1999), yakni: komunikasi massa adalah pesan yang dikomunikasikan melalui media massa pada sejumlah besar orang (mass communication is messages communicated through a mass medium to a large number of people). Dari definisi tersebut dapat diketahui bahwa komunikasi massa itu harus menggunakan media massa. Jadi sekalipun komunikasi itu disampaikan kepada khalayak yang banyak, seperti rapat akbar di lapangan luas yang dihadiri oleh ribuan, bahkan puluhan ribu orang, jika tidak menggunakan media massa, maka itu bukan komunikasi massa. Media komunikasi yang termasuk media massa adalah radio siaran, dan televisi- keduanya dikenal sebagai media elektronik; surat kabar dan majalah- keduanya disebut dengan media cetak; serta media film. Film sebagai media komunikasi massa adalah film bioskop.

2. Definisi komunikasi massa yang lebih rinci dikemukakan oleh ahli komunikasi yang lain, yaitu Gebner. Menurut Gerbner (1967) "Mass communication is the tehnologically and institutionally based production and distribution of the most broadly shared continous flow of messages in industrial societes". (Komunikasi massa adalah produksi dan distribusi yang berlandaskan teknologi lembaga dari arus pesan yang kontinyu serta paling luas dimiliki orang dalam masyarakat indonesia (rakhmat, seperti yang 
dikutip Komala, dalam Karnilah, dkk.1999). Dari definisi Gerbner tergambar bahwa komunikasi massa itu menghasilkan suatu produk berupa pesan-pesan komunikasi. Produk tersebut disebarkan, didistribusikan kepada khalayak luas secara terus menerus dalam jarak waktu yang tetap, misalnya harian, mingguan, dwimingguan atau bulanan. Proses memproduksi pesan tidak dapat dilakukan oleh perorangan, melainkan harus oleh lembaga, dan membutuhkan suatu teknologi tertentu, sehingga komunikasi massa akan banyak dilakukan oleh masyarakat industri.

3. Definisi komunikasi massa dari Meletzke berikut ini memperlihatkan massa yang satu arah dan tidak langsung sebagai akibat dari penggunaan media massa, juga sifat pesannya yang terbuka untuk semua orang. Dalam definisi Meletzke, komunikasi massa diartikan sebagai setiap bentuk komunikasi yang menyampaikan pernyataan secara terbuka melalui media penyebaran teknis secara tidak langsung dan satu arah pada publik yang tersebar (Rakhmat seperti yang dikutip dalam Komala, dalam Karlinah. 1999). Istilah tersebar menunjukkan bahwa komunikan sebagai pihak penerima pesan tidak berada di suatu tempat, tetapi tersebar di berbagai tempat.

\subsubsection{Model Komunikasi Massa}

Komunikasi dengan menggunakan media massa dalam tahun terakhir ini banyak mendapat kajian dari para ahli disebabkan semkin majunya teknologi di bidang media massa. Kemajuan teknlogi di bidang pers seperti kepastian percetakan yang mampu menghasilkan ratusan ribu bahkan jutaan eksemplar surat kabar dalam waktu yang relatif cepat; kemajuan teknologi dibidang film yang berhasil menyempurnakan segi audio dan visual; kemajuan teknologi dibidang radio yang mampu menjangkau jarak yang lebih jauh dengan suara yang lebih baik; kemajuan teknologi dibidang televisi yang dengan satelitnya mampu menghubungkan satu bangsa dengan bangsa lain secara visua auditif, hidup dan pada saat suatu peristiwa terjadi; itu semua berpengaruh besar pada kehidupan politik, sosial, ekonomi dan kebudayaan. 
Kajian para ahli tersebut menghasilkan teori komunikasi massa diantaranya :

a. Model jarum hipodermik (hypodermic needle model)

Secara harfiah "hypodermic" berarti "dibawah kulit". Dalam hubungannya dengan komunikasi massa istilah hypodermic needle model mengandung anggapan dasar bahwa media massa menimbulkan efek yang kuat, terarah, segera dan langsung itu adalah sejalan dengan pengertian "perangsang tanggapan (stimulus-response)" yang mulai dikenal sejak kajian ilmujiwa pada tahun 1930an.

Media massa dikabarkan sebagai jarum hipodermik raksasa yang mencotok massa komunikan yang pasif Elihu katz mengatakan, bahwa model tersebut terdiri dari:

1. Media yang sangat ampuh yang mampu memasukkan idea pada benak yang tidak berdaya.

2. Massa komunikan yang terpecah-pecah, yang terhubungkan dengan media massa, tetapi sebaiknya komunikan tidak terhubungkan satu sama lain.

\section{b. Model Komunikasi satu tahap (One Step Flow Model)}

Model komunikasi satu tahap ini menyatakan bahwa saluran media massa berkomunikasi langsung dengan assa komunikan tanpa berlalunya suatu pesan melalui orang lain, tetapi pesan tersebut tidak mencapai semua komuikan dan tidak menimbulkan efek yang sama pada setiap komunikan.

Model komunikasi satu tahap adalah model jarum hipodermik yang dimurnikan, model mana letak kita bicarakan dimuka. Tetapi model satu tahap mengakui bahwa:

1. Media tidak mempunyai kekuatan yang hebat.

2. Aspek pilihan dari penampilan, penerimaan, dan penahanan dalam ingatan yang selektif mempengaruhi suatu pesan.

3. untuk setiap komunikan terjadi efek yang berbeda.

Selanjutnya model satu tahap memberi keleluasaan kepada saluran komunikasi massa untuk memancarkan efek komunikasi secara langsung. 


\section{c. Model Komunikasi dua Tahap (two step flow model)}

Konsep komunikasi dua tahap ini berasal dari lazarsfeld, Berelson, dan Gaudet (1948) yang berdasarkan penelitiannya manyatakan bahwa idea-idea sering kali datang dari radio dan surat kabar yang ditangkap oleh pemuka pendapat (opinion leaders) dan dari mereka ini berlaku menuju penduduk yang kurang giat. Tahap pertama adalah dari sumbernya, yakni komunikator dari pemuka pendapat kepada pengikut-pengikutnya, yang juga menyangkut penyebaran pengaruh.

Model dua tahap ini menyebabkan kita menaruh perhatian kepada peranan media massa dan komunikasi antarpribadi. Berlainan dengan model jarum hipodermik yang beranggapan, bahwa massa merupakan tubuh besar yang terdiri dari orang-orang yang tak berhubungan tetapi berkaitan kepada media, maka model dua tahap meliat massa sebagai perorangan yang berinteraksi. Ini menyebabkan penduduk terbawa kembali ke komunikasi massa.

Kajian terhadap model ini selain menimbulkan keuntungan, juga telah menjumpai kekurangan. Pada dasarnya model ini tidak memberikan penjelasan yang cukup. Apa yang diketahui tentang proses komunikasi massa ternyata terlalu mendetail untuk diterangkan dengan satu kalimat saja meskipu demikian, dari kajian komunikasi timbul dua keuntungan dari hipotesis dua tahap tersebut:

1. Suatu pemusatan kegiatan terhadap kepemimpinan opini dalam komunikasi massa.

2. Beberapa perbaikan dari komunikasi dua tahap, seperti komunikasi dua tahap dan komunikasi tahap ganda.

\section{d. Model Komunikasi Tahap Ganda (Multi Step Flow Model)}

Model ini menggabungkan semua model yang telah dibicarakan terlebih dahulu. Model banyak tahap ini didasrkan pada fungsi penyebaran yang berurutan yang terjadi pada kebanyakan situasi komunikasi. Ini tidak mencakup jumlah tahap secara khusus, juga tidak khusus bahwa suatu pesan harus berlangsung dari komunikator melalui saluran media massa. Model ini menyatakan bahwa bagi 
lajunya komunikasi dari komunikaator kepada komunikan terdapat jumlah "relay" yang berganti-ganti. Beberapa komunikan menerima pesan langsung melalui saluran dari komuikator yang lainnya terpindahkan dari sumbernya beberapa kali.

Jumlah tahap yang pasti dalam proses ini bergantung pada maksud tujuan komunikator, tersedianya media massa dengan kemampuannya untukk menyebarkannya, sifat dari pesan, dan nilai pentingnya pesan bagi komunikan.

\subsubsection{Ciri-Ciri Komunikasi Massa}

1. Komunikator dalam Komunikasi Massa Melembaga

Komunikator dalam komunikasi massa bukan satu orang, tetapi kumpulan orang. Artinya, gabungan antar berbagai macam unsur dan bekerja sama satu sama lain dalam sebuah lembaga. Lembaga yang dimaksud disini menyerupai sebuah sistem. Sistem itu adalah sekelompok orang, pedoman, dan media yang melakukan suatu kegiatan mengolah, menyimpan, menuangkan ide, gagasan,simbol, lambang menjadi pesan dalam membuat keputusan untuk mencapai suatu kesepakatan dan saling pengertian satu sama lain dengan mengolah pesan itu menjadi sumber informasi.

2. Komunikasi dalam Komunikasi Massa Bersifat Heterogen

Komunikan dalam komunikasi massa sifatnya heterogen. Artinya, komunikan terdiri dari beragam pendidikan, umur, jenis kelamin, status sosial ekonomi, jabatan yang beragam, dan memiliki agama atau kepercayaan yang berbeda pula.

Herbert Blumer pernah memberikan ciri tentang karakteristik audience (komunikan) sebagai berikut:

1. Audience dalam komunikasi massa sangatlah heterogen. Artinya, ia mempunyai heterogenitas komposisi atau susunan. Jika ditinjau dari asalnya, mereka berasal dari berbagai kelompok dalam masyarakat. 
2. Berisi individu - individu yang tidak mengenal satu sama lain. Disamping itu, antar individu itu tidak berinteraksi langsung satu sama lain.

3. Mereka tidak mempunyai kepemimpinan atau organisasi formal

\section{Pesannya Bersifat Umum.}

Pesan-pesan dalam komunikasi massa tidak ditujukan ke pada satu orang atau kelompok masyarakat tertentu. Dengan kata lain, pesan - pesannya ditujukan kepada khalayak yang plural. Karena itu, pesan- pesan yang dikemukakan tidak boleh bersifat khusus.

4. Komunikasinya Berlangsung Satu Arah

Pada media massa, komunikasi hanya berjalan satu arah. Kita tidak bisa langsung memberikan respon kepada komunikatornya (media massa yang bersangkutan). Kalaupun bisa, sifatnya tertunda.

5. Komunikasi Massa Menimbulkan Keserempakan

Salah satu ciri komunikasi massa selanjutnya adalah keserempakan proses penyebaran pesannya. Serempak berarti khalayak bisa menikmati media massa tersebut hampir bersamaan.

6. Komunika si Massa Mengandalkan Peralatan Teknis

Media massa sebagai alat utama menyampaikan pesan kepada khalayaknya sangat membutuhkan peralatan teknis. Peralatan teknis misalnya pemancar untuk media elektronik (mekanik atau elektronik). Dewasa ini telah terjadi revolusi komunikasi massa dengan perantaraan satelit. Peran satelit akan memudahkan proses pemancaran pesan yang dilakukan media elektronik seperti televisi. Bahkan saat ini sudah sering televisi menyajikan siaran langsung (live) dan bukannya rekaman (recorded ).

7. Komunikasi Massa Dikontrol oleh Gatekeeper

Gatekeeper atau yang sering disebut penapis informasi adalah orang yang sangat berperan dalam penyebaran informasi melalui media massa. Gatekeeper berfungsi sebagai orang yang ikut menambah atau 
mengurangi, menyederhanakan, mengemas agar semua informasi yang disebarkan lebih mudah dipahami. Gatekeeper juga berfungsi menginterpretasikan pesan, menganalisis, menambah data, dan mengurangi pesan- pesannya. Intinya, gatekeeper merupakan pihak yang ikut menentukan pengemasan sebuah pesan dari media massa. Semakin kompleks sistem media yang dimiliki, semakin banyak pula (pemalang pintu atau penapis informasi) yang dilakukan. Bahkan, gatekeeper sangat menentukan berkualitas atau tidaknya informasi yang akan disebarkan.

\subsubsection{Fungsi Komunikasi Massa}

Dalam pembicaraan fungsi fungsi dari komunikasi massa kita harus melihat media massa di dalamnya. Dikarenakan komunikasi massa yaitu komunikasi yang dilakukan melalui media massa. Komunikasi massa tidak akan terjadi bila tidak ada media massa sebagai elemen terpenting di dalamnya.

Terdapat fungsi sebagai berikut:

\section{Informasi}

Fungsi informasi merupakan fungsi paling penting yang terdapat dalam komunikasi massa. Komponen paling penting untuk mengetahui fungsi informasi ini adalah berita-berita yang disajikan. Fakta-fakta yang dicari wartawan di lapangan kemudian dituangkannya dalam tulisan juga merupakan informasi. Fakta yang dimaksud adalah adanya kejadian yang benar-benar terjadi di masyarakat.

\section{Hiburan}

Fungsi hiburan untuk media elektronik menduduki posisi yang paling tinggi dibandingkan dengan fungsi-fungsi yang lain. Masalahnya, masyarakat kita masih menjadikan televisi sebagai media hiburan. Hal ini mendudukkan televisi sebagai alat utama hiburan (untuk melepas lelah). Oleh karena itu, jangan heran jika jam-jam prime time (pukul 19.00 sampai 21.00) akan disajikan acara-acara hiburan, entah sinetron, kuis, atau acara jenaka lainnya.

3. Persuasi 
Fungsi persuasif komunikasi massa tidak kalah pentingnya dengan fungsi informasi dan hiburan. Banyak bentuk tulisan yang kalau diperhatikan sekilas hanya berupa informasi, tetapi jika diperhatikan secara lebih jeli ternyata terdapat fungsi persuasi. Bagi Josep A. Devito (1997) fungsi persuasi dianggap sebagai fungsi yang paling penting dari komunikasi massa. Persuasi bisa datang dari berbagai macam bentuk: Pertama, mengukuhkan atau memperkuat sikap, kepercayaan, atau nilai seseorang; Kedua, mengubah sikap, kepercayaan, atau nilai seseorang; Ketiga, menggerakkan seseorang untuk melakukan sesuatu; dan Keempat, memperkenalkan etika, atau menawarkan sistem nilai tertentu.

4. Transmisi budaya

Transmisi budaya merupakan salah satu fungsi komunikasi massa yang paling luas, meskipun paling sedikit dibicarakan. Transmisi budaya tidak dapat dielakkan selalu hadir dalam berbagai bentuk komunikasi yang mempunyai dampak pada penerimaan individu. Transmisi budaya mengambil tempat dalam dua tingkatan, kontemporer dan historis. Di dalam tingkatan kontemporer, media massa memperkuat konsensus nilai masyarakat, dengan selalu memperkenalkan bibit perubahan secara terus menerus. Hal ini merupakan faktor yang memberi petunjuk tekateki yang mengitari media massa, mereka secara serempak pengukuh status quo dan mesin perubahan. Sementara itu, secara historis umat manusia telah dapat melewati atau menambahkan pengalaman baru dari sekarang untuk membimbingnya ke masa depan.

5. Medorong kohesi sosial

Kohesi yang dimaksud di sini adalah penyatuan. Artinya, media massa mendorong masyarakat untuk bersatu. Dengan kata lain, media massa merangsang masyarakat untuk memikirkan dirinya bahwa bercerai-berai bukan keadaan yang baik bagi kehidupan mereka. Media massa yang memberitakan arti pentingnya kerukunan hidup umat beragama, sama saja media massa itu mendorong kohesi sosial. Akan tetapi, ketika 
media massa mempunyai fungsi untuk menciptakan integrasi sosial, sebenarnya di sisi lain media juga memiliki peluang untuk menciptakan disintegrasi sosial. Jadi, sebenarnya peluang untuk menciptakan integrasi dan disintegrasi sama besarnya

\section{Pengawasan}

Bagi Laswell, komunikasi massa mempunyai fungsi pengawasan. Artinya, menunjuk pada pengumpulan dan penyebaran informasi mengenai kejadian-kejadian yang ada di sekitar kita. Fungsi pengawasan bisa dibagi menjadi dua, yakni warning or beware surveillance atau pengawasan peringatan dan instrumental surveillance atau pengawasan instrumental.

7. Korelasi

Fungsi korelasi yang dimaksud adalah fungsi yang menghubungkan bagian-bagian dari masyarakat agar sesuai dengan lingkungannya. Erat kaitannya dengan fungsi ini adalah peran media massa sebagai penghubung antara berbagai komponen masyarakat. Bagi Charles R. Wright fungsi korelasi juga termasuk menginterpretasikan pesan yang menyangkut lingkungan dan tingkah laku tertentu dalam mereaksi kejadian-kejadian. Salah satu bagian terpenting dalam menjalankan fungsi korelasi yang termasuk interpretasi bila dilihat dari Tajuk Rencana atau Hoofd Artikel (Belanda),Leader/Leader Writer (Inggris) sebuah surat kabar, meskipun tajuk rencana juga memiliki fungsi persuasi.

\subsubsection{Tujuan Komunikasi Massa}

Tujuan dari komunikasi adalah seperti yang dikemukakan oleh Dan B. Curtis dalam buku Komunikasi Bisnis Profesional sebagai berikut :Memberikan informasi, kepada para klien, kolega, bawahan dan penyelia (supervisor)Diberi informasi, karena perilaku diberi informasi merupakan bentuk interaksi komunikasi. Orang atau masyarakat cenderung merasa lebih baik diberi informasi 
yang diperlukannya atau yang akan diberi jalan masuk menuju informasi tersebut yang merupakan bagian dari keadaan percaya dan rasa aman.

Menolong orang lain, memberikan nasihat kepada orang lain, ataupun berusaha memotivasi orang lain dalam mencapai tujuan.Menyelesaikan masalah dan membuat keputusan, karena semakin tinggi kedudukan/status seseorang maka semakin penting meminta orang lain untuk keahlian teknis sehingga dalam menyelesaikan masalah/membuat keputusan tersebut harus ada komunikasi untuk meminta data sebagai bahan pertimbangan.

Mengevaluasi perilaku secara efektif, yaitu suatu penilaian untuk mengetahui hal-hal yang akan mereka lakukan setelah menerima massege. (1992 : 9) Sementara itu menurut Onong Uchjana Effendi dalam buku Dimensi - dimensi Komunikasi tujuan komunikasi adalah sebagai berikut :

1. Perubahan Sosial dan partisipasi sosial. Memberikan berbagai informasi pada masyarakat tujuan akhirnya supaya masyarakat mau mendukung dan ikut serta terhadap tujuan informasi itu disampaikan. Misalnya supaya masyarakat ikut serta dalam pilihan suara pada pemilu atau ikut serta dalam berperilaku sehat, dan sebagainya.

2. Perubahan Sikap. Kegiatan memberikan berbagai informasi pada masyarakat dengan tujuan supaya masyarakat akan berubah sikapnya. Misalnya kegiatan memberikan informasi mengenai hidup sehat tujuannya adalah supaya masyarakat mengikuti pola hidup sehat dan sikap masyarakat akan positif terhadap pola hidup sehat.

3. Perubahan pendapat. Memberikan berbagai informasi pada masyarakat tujuan akhirnya supaya masyarakat mau berubah pendapat dan persepsinya terhadap tujuan informasi itu disampaikan, misalnya dalam informasi mengenai pemilu. Terutama informasi mengenai kebijakan pemerinatah yang biasanya selalu mendapat tantangan dari masyarakat maka harus disertai penyampaian informasi yang lengkap supaya pendapat masyarakat dapat terbentuk untuk mendukung kebijakan tersebut.

4. Perubahan perilaku. Kegiatan memberikan berbagai informasi pada masyarakat dengan tujuan supaya masyarakat akan berubah perilakunya. 
Misalnya kegiatan memberikan informasi mengenai hidup sehat tujuannya adalah supaya masyarakat mengikuti pola hidup sehat dan perilaku masyarakat akan positif terhadap pola hidup sehat atau mengikuti perilaku hidup sehat.

\subsubsection{Komunikasi Massa Dalam Pembangunan}

Dengan melihat karakteristik yang dimiliki oleh media massa, sangat mungkin informasi mengenai program - program pembangunan dapat disebarkan secara luas dan serempak. Sehingga dapat membantu proses penyebaran informasi pembangunan secara efektif. Adapun peran media massa dalam pelaksanaan program pembangunan menurut Schraam (dalam Zulkarimen Nasution, 1992:55) yaitu:

1. Menyampaikan kepada masyarakat informasi tentang pembangunan nasional, agar mereka memusatkan perhatian pada kebutuhan akan perubahan, kesempatan dan cara mengadakan perubahan, dan membangkitkan aspirasi nasional.

2. Memberikan kesempatan pada masyarakat untuk mengambil bagian secara aktif dalam proses pengambilan keputusan, memperluas dialog agar melibatkan semua pihak yang akan membuat keputusan mengenai perubahan, memberikan kesempatan kepada pemimpin untuk memimpin dan mendengarkan pendapat rakyat kecil dan menciptakan arus informasi yang berjalan lancar dari bawah ke atas

3. Mendidik tenaga kerja yang diperlukan pembangunan, sejak anak - anak hingga dewasa, sejak pelajaran baca tulis hingga keterampilan teknis yang mengubah hidup masyarakat.

4. Dari uraian di atas dapat di katakan bahwa dalam pelaksanaan program pembangunan, media massa memiliki peran penting terutama dalam penyebaran informasi pembangunan nasional. 


\subsubsection{Komunikasi Massa Dalam Politik}

Sebagaimana yang telah kita ketahui bahwa begitu besar peran komunikasi massa atau media massa dalam kehidupan masyarakat, yang mampu mempengaruhi dan merubah cara pikir suatu kelompok masyarakat. Akan tetapi kekuatan media massa ini juga digunakan oleh pemerintah maupun suatu kelompok masyarakat di suatu pemerintahan untuk mempengaruhi opini publik. Dalam dunia politik pun media massa digunakan sebagai alat penyampaian informasi dan pesan yang sangat efektif dan efisien . Menurut Gurevitch dan Blumer (1990:270) fungsi-fungsi media massa adalah:

1. Sebagai pengamat lingkungan dari kondisi sosial politik yang ada. Media massa berfungsi sebagai alat kontrol sosial politik yang dapat memberikan berbagai informasi mengenai penyimpangan sosial itu sendiri, yang dilakukan baik oleh pihak pemerintah, swasta, maupun oleh pihak masyarakat.

2. Sebagai pembentuk agenda (agenda setting) yang penting dalam isi pemberitaannya. Pembentukan opini dengan cara pembentukan agenda atau pengkondisian politik sehingga masyarakat terpengaruh untuk mengikuti dan mendukung rencana-rencana pemerintah. Contohnya: wacana pembatasan subsidi BBM untuk sepeda motor, SKPP BibitCandra, dan lain-lain.

3. Komunikasi massa merupakan platform (batasan) dari mereka yang punya advokasi dengan bukti-bukti yang jelas bagi para politisi, jurubicara, dan kelompok kepentingan. Ada pembagian lain dari komunikator politik, yaitu yang disebut dengan komunikator profesional (Carey, 1969). Pembagian ini muncul karena kemajuan-kemajuan dalam dunia teknologi komunikasi. Sehingga ada batasan/pembagian tugas dan peranan penyampaian pesan politik.

4. Komunikasi massa mampu menjadi tempat berdialog tentang perbedaan pandangan yang ada dalam masyarakat atau diantara pemegang kekuasaan (yang sekarang maupun yang akan datang). Media massa sebagai sarana untuk menampung berbagai pendapat, pandangan, dan paradigma dari 
masyarakat yang ingin ikut andil dalam membangun sistem politik yang lebih baik.

5. Komunikasi massa merupakan bagian dari mekanisme penguasa untuk mempertahankan kedudukannya melalui keterangan-keterangan yang diungkapkan dalam media massa. Hal ini kerap terjadi pada masa Orba, ketika masa Presiden Soeharto berkuasa yang selalu menyampaikan keberhasilan-keberhasilan dengan maksud agar masyarakat mengetahui bahwa pemerintahan tersebut harus dipertahankan apabila ingin mengalami kemajuan yang berkesinambungan.

6. Komunikasi Massa bisa merupakan insentif untuk publik tentang bagaimana belajar, memilih, dan menjadi terlibat daripada ikut campur dalam proses politik. Keikutsertaan masyarakat dalam menentukan kebijakan politik bisa disampaikan melalui media massa dengan partisipasi dalam poling jajak pendapat dan dialog interaktif. Hasil dari poling atau jajak pendapat tersebut akan merefleksikan arah kebijakan para politisi. Seperti hasil poling akhir-akhir ini dinyatakan bahwa sebagian besar masyarakat pemilih pada pemilu 2009, mengharapkan pemerintah hasil Pemilu dapat memprioritaskan perbaikan ekonomi. Hanya sebagian kecil dari masyarakat yang memilih untuk prioritas pemberantasan korupsi. Hal ini yang menjadi kekhawatiran para aktivis anti korupsi bahwa hasil itu akan mempengatuhi arah kebijakan pemerintah sebagai kecenderungan sebagian besar kelompok masyarakat.

7. Komunikasi massa bisa menjadi penentang utama terhadap semua upaya dari kekuatan-kekuatan yang datang dari luar media massa dan menyusup ke dalam kebebasannya,integritasnya, dan kemampuannya di dalam melayani masyarakat. Fakta-fakta kebenaran yang diungkapkan oleh media massa dapat menyadarkan masyarakat tentang adanya kekuatankekuatan berupa terorisme atau premanisme, maupun intimidasi dari pihak-pihak tertentu yang mencoba mengkaburkan suatu permasalahan. 


\section{HASIL KAJIAN DAN PEMBAHASAN}

Berdasarkan data hasil kajian tentang hubungan komunikasi massa melalui radio desa terhadap partisipasi masyarakat dalam kegiatan desa. Maka selanjutnya penulis akan menampilkan data deskriftif kuantitatif dengan menggunakan tabel distribusi frekuensi, grafik dan prosentase, sebagai berikut:

\subsection{Variabel (X) Tentang Komunikasi Massa Dengan Menggunakan Radio}

Berdasarkan atas hasil penelitian, nampaknya kajian tentang hubungan komunikasi massa melalui radio desa terbagi atas beberapa pertanyaan, sebagi berikut:

\subsubsection{Indikator (X 1) Menyampaikan informasi Pembangunan}

Terkait dengan radio mampu menyampaikan informasi pembangunan dapat diuraikan kedalam dua pertanyaan, antara lain:

a) Apakah anda selalu mendapatkan informasi tentang pembangunan melalui Radio Desa.

Berdasarkan atas hasil penelitian, nampaknya peran Radio Desa mampu memberikan informasi tentang pembangunan, hal tersebut terbukti dari 50 prosen responden menyatakan bahwa keberadaan radio desa mampu memberikan informasi pembangunan. Tanggapan responden, terkait pertanyaan tentang radio desa memberikan informasi pembangunan, semua responden (baca:100 prosen) sepakat bahwa radio desa mampu memberikan informasi pembangunan.

b). Apakah Pemerintah Desa Selalu Memberikan Informasi Pembangunan Melalui Radio Desa

Berdasarkan atas hasil penelitian, nampaknya pemerintah desa selalu memberikan informasi tentang pembangunan melalui Radio Desa, hal tersebut terbukti dari 50 prosen responden menyatakan bahwa keberadaan radio desa mampu memberikan informasi pembangunan. Tanggapan responden, terkait pertanyaan tentang pemerintah desa selalu memberikan informasi tentang pembangunan melalui Radio Desa, semua responden (baca:100 prosen) sepakat 
bahwa pemerintah desa selalu memberikan informasi tentang pembangunan melalui Radio Desa. Selanjutnya berdasarkan kedua pertanyaan di atas, dapat diambil kesimpulan bahwa responden merasa siaran radio desa memiliki manfaat bagi optimalisasi pembangunan yang ada di Desa.

\subsubsection{Indikator (X 2) Radio Desa Memberikan Kesempatan Pada Masyarakat Untuk Berpartisipasi}

Tanggapan responden, terkait radio desa memberikan kesempatan pada masyarakat untuk berpartisipasi. Mayoritas yakni 75 prosen responden menyatakan bahwa radio desa memberikan kesempatan pada masyarakat untuk berpartisipasi. Sisanya (25 prosen) menyatakan bahwa radio desa memberikan kesempatan pada masyarakat untuk berpartisipasi. Berdasarkan hal tersebut penulis mengambil kesimpulan bahwa responden tahu dan mengamati bahwa radio desa memberikan kesempatan pada masyarakat untuk berpartisipasi.

\subsubsection{Indikator (X 3) Memberikan Pembelajaran Pada Masyarakat Untuk siap menjadi Tenaga Pembangunan}

Tanggapan responden, terkait pertanyaan tentang penilaian terhadap radio desa memberikan pembelajaran pada masyarakat untuk siap menjadi tenaga pembangunan, mayoritas responden menyatakan bahwa 83 prosen sepakat radio desa memberikan pembelajaran pada masyarakat untuk siap menjadi tenaga pembangunan. Lebih lanjut informasi yang di dengar masyarakat dari Radio Desa sangat beragam, terutama terlihat dari banyaknya masyarakat yang mendengar pada acara musik dan berita, hal tersebut bukan tanpa alasan.

\subsubsection{Indikator (X 4) Radio Desa Sebagai Alat Kontrol Sosial}

Berdasarkan atas hasil kajian terkait dengan Radio Desa sebagai alat kontrol terbagi ke dalam 2 pertanyaan, antara lain:

a). Radio Desa Sebagai Alat Kontrol Sosial

Tanggapan responden, terkait pertanyaan tentang radio desa sebagai alat kontrol sosial, mayoritas yakni 83 prosen responden sepakat bahwa radio desa 
sebagai alat kontrol sosial. Bahkan ada 40 prosen yang menyatakan sangat setuju radio desa sebagai alat kontrol sosial. Berdasarkan hal tersebut penulis mengambil kesimpulan bahwa radio desa tersebut memiliki potensi untuk menjadi radio yang maju untuk sebagai kontrol sosial.

\section{b). Radio Desa Sebagai Kontrol Pemerintah}

Tanggapan responden, terkait pertanyaan tentang radio desa sebagai kontrol pemerintah. Mayoritas yakni 83 persen responden menyatakan bahwa radio desa cukup efektif, bahkan sebagian responden menyatakan sangat efektif. Berdasarkan hal tersebut penulis mengambil kesimpulan pada pertanyaan ini, bahwa mayoritas responden memahami makna penting radio desa, oleh karena itu hal tersebut menjadi modal sosial bagi radio desa dalam turut serta dalam pembangunan. Hanya 17 responden yang menyatakan tidak efektif dan membosankan.Hasil survei penulis yang menunjukan bahwa 83 prosen masayarakat menganggap efektif acara yang disiarkan oleh radio desa bukan tanpa alasan.

\subsubsection{Indikator (X 5) Radio Desa Sebagai Tempat Berdialog}

Tanggapan responden, terkait radio desa sebagai tempat berdialog mayoritas yakni 83 persen responden menyatakan sangat setuju sebagai sarana dialag, bahkan sebagian responden menyatakan sangat setuju sebagai sarana dialog. Berdasarkan hal tersebut penulis mengambil kesimpulan pada pertanyaan ini, bahwa mayoritas responden mengetahui bahwa radideo desa sebagai sarana dialog yang efektif, oleh karena itu hal tersebut menjadi modal sosial bagi radio desa dalam turut serta dalam pembangunan. Hanya 17 responden yang menyatakan tidak setuju dan lain-lain. Terkait Radio Desa sebagai sarana diolog, nampaknya mayoritas resopnden menjawab sangat setuju dan setuju (obyektif). 


\subsubsection{Indikator (X $\quad$ 6) Peran Radio Desa Sarana Pemerintah Mempertahankan Kedudukan}

Tanggapan responden, terkait pertanyaan tentang peran radio desa sarana pemerintah mempertahankan kedudukan, sebanyak 16 prosen responden sering. Bahkan sering menyatakan 69 prosen responden yang mengatakan hal tersebut. Sedangkan 23 sangat sering. Berdasarkan hal tersebut, penulis menyimpulkan bahwa responden menyatakan bahwa mampu membangun dan mempertahankan kedudukan pejabat politik di desa. Hasil survei penulis yang menunjukan bahwa 83 prosen masayarakat menganggap efektif acara yang disiarkan oleh radio desa bukan tanpa alasan.

\subsubsection{Indikator (X 7) Peran Radio Desa Dalam Mendukung Program Pemerintah Desa}

Tanggapan responden, terkait pertanyaan tentangapakah siaran radio desa mendukung kegiatan pemerintah desa. 23 prosen responden sepakat bahwa siaran radio desa mendukung kegiatan pemerintah desa. Namun mayoritas responden menyatakan bahwa radio desa mendukung kegiatan Pemerintah Desa.

\subsection{Variabel (Y) Tentang Indikator Partisipasi Masyarakat Dalam Pembangunan Desa}

Berdasarkan atas hasil penelitian, nampaknya kajian tentang hubungan radio desa terhadap partisipasi masyarakat setuju melalui tenaga, dana dan keterampilan dalam program dan kegiatan desadapat dilihat pada tabel di bawah ini:

\subsubsection{Indikator (Y 1) Partisipasi Publik Dalam Bentuk Uang}

Tanggapan responden, terkait pertanyaan tentang dampak adanya radio desa terhadap peningkatan partisipasi publik dalam bentuk partisipasi anggaran (uang). Mayoritas yakni 83 persen responden menyatakan setuju, bahkan sebagian responden menyatakan sangat setuju. Berdasarkan hal tersebut penulis mengambil kesimpulan pada pertanyaan ini, bahwa mayoritas responden memahami makna 
penting radio desa, oleh karena itu hal tersebut menjadi modal sosial bagi radio desa dalam turut serta dalam pembangnan. Hanya 17 responden yang menyatakan tidak setuju(tidak efektif) dan membosankan. Hasil survei penulis yang menunjukan bahwa 83 prosen bahwa dampak adanya radio desa terhadap peningkatan partisipasi publik dalam bentuk partisipasi anggaran (uang).

\subsubsection{Indikator (Y 2) Masyarakat Tergerak Secara Tenaga Untuk Berpartisipasi Dengan Harta Benda Akibat Adanya Radio Desa}

Tanggapan responden, terkait pertanyaan tentang radio desa dalam meningkatkan partisipasi masyarakat melaluimelalui harta benda yang mereka miliki. Mayoritas yakni 83 persen responden menyatakan setuju (efektif), bahkan sebagian responden menyatakan sangat efektif. Berdasarkan hal tersebut penulis mengambil kesimpulan pada pertanyaan ini, bahwa mayoritas responden memahami makna penting radio desa dalam meningkatkan partisipasi masyarakat melalui tenaga, dana dan keterampilan, oleh karena itu hal tersebut menjadi modal sosial bagi radio desa dalam turut serta dalam pembangnan. Hanya 17 responden yang menyatakan tidak setuju (tidak efektif).

\subsubsection{Indikator (Y 3) Masyarakat Tergerak (Tenaga) Untuk Berpartisipasi Dengan Adanya Radio Desa}

Tanggapan responden, terkait pertanyaan tentang masyarakat merasa tergerak untuk berpartisipasi lebih dengan adanya siaran radio desa. Mayoritas yakni 63 persen responden menyatakan setuju (efektif) bahwa radio desa cukup mampu menggerakkan partisipasi masyarakat, oleh karena itu maka dalam siarannya hendaknya radio desa mampu menampilkan kegiatan yang bisa terus menggugah semangat masyarakat untuk terus berpartisipasi dalam pembangunan desa.Berdasarkan hasil kajian lebih yang dilakukan oleh peneliti, nampaknya Radio Desa cukup efektif menggerakkan partisipasi masyarakat.

Berdasarkan hasil riset yang dilakukan oleh penulis ini nampaknya, arah perkembangan Radio Desa sangap potensial, karena adanya antusiasme dan 
kepercayaan serta dukungan masyarakat terhadap Radio Desa yang terus meningkat dari waktu ke waktu.

\subsubsection{Indikator (Y 4) Dampak Adanya Radio Desa Terhadap Peningkatan Partisipasi Publik Dalam Bentuk Keterampilan}

Tanggapan responden, terkait pertanyaan tentang dampak adanya radio desa terhadap peningkatan partisipasi publik dalam bentuk keterampilan. Mayoritas yakni 83 persen responden menyatakan setuju, bahkan sebagian responden menyatakan sangat setuju. Berdasarkan hal tersebut penulis mengambil kesimpulan pada pertanyaan ini, bahwa mayoritas responden memahami makna penting radio desa, oleh karena itu hal tersebut menjadi modal sosial bagi radio desa dalam turut serta dalam pembangnan. Hanya 17 responden yang menyatakan tidak setuju (tidak efektif) dan membosankan. Hasil survei penulis yang menunjukan bahwa 83 prosen bahwa dampak adanya radio desa terhadap peningkatan keterampilan publik.

\subsubsection{Indikator (Y 5) Komunikasi Massa Melalui Radio Desa Terhadap Peningkatan Partisipasi Publik Dalam Bentuk Buah Pikiran}

Tanggapan responden, terkait pertanyaan tentang dampak adanya radio desa terhadap peningkatan partisipasi publik dalam bentuk buah pikiran. Mayoritas yakni 83 persen responden menyatakan setuju, bahkan sebagian responden menyatakan sangat setuju. Berdasarkan hal tersebut penulis mengambil kesimpulan pada pertanyaan ini, bahwa mayoritas responden memahami makna penting radio desa, oleh karena itu hal tersebut menjadi modal sosial bagi radio desa dalam turut serta dalam pembangnan. Hanya 17 responden yang menyatakan tidak setuju dan membosankan.

\subsubsection{Indikator (Y 6) Radio Desa Terhadap Peningkatan Partisipasi Sosial Masyarakat \\ Tanggapan responden, terkait pertanyaan tentang dampak adanya radio desa terhadap peningkatan partisipasi publik dalam bentuk buah pikiran.}


Mayoritas yakni 100 persen responden menyatakan setuju, bahkan sebagian responden menyatakan sangat setuju. Berdasarkan hal tersebut penulis mengambil kesimpulan pada pertanyaan ini, bahwa mayoritas responden memahami makna penting radio desa, oleh karena itu hal tersebut menjadi modal sosial bagi radio desa dalam turut serta dalam pembangnan. Hasil survei penulis yang menunjukan bahwa 100 prosen bahwa dampak adanya radio desa terhadap peningkatan partisipasi sosial.

\subsubsection{Indikator (Y 7) Radio Desa Terhadap Peningkatan Partisipasi Dalam Keterlibatan Publik Pengambilan Keputusan}

Tanggapan responden, terkait pertanyaan tentang Dampak Adanya Radio Desa Terhadap Peningkatan Partisipasi Dalam Keterlibatan Publik Pengambilan Keputusan. Mayoritas yakni 100 persen responden menyatakan setuju bahwa publik terlibat dalam ikut serta dalam pengambilan keputusan, bahkan sebagian responden menyatakan sangat setuju. Berdasarkan hal tersebut penulis mengambil kesimpulan pada pertanyaan ini, bahwa mayoritas responden memahami makna penting radio des dalam mendorong partisipasi publik.

\subsection{Variabel Komunikasi Massa Dengan Menggunakan Radio (X) dan Indikator Partisipasi Masyarakat Dalam Pembangunan Desa (Y)}

Berdasarkan atas hasil penelitian, nampaknya kajian tentang hubungan komunikasi massa (radio desa) terhadap partisipasi masyarakat dalam menikatkan partisipasi masyarakat dalam program dan kegiatan desa, dapat dilihat pada pembahasan dibawah ini:

\subsubsection{Indikator Radio Desa Mempengaruhi Opini dan Partisipasi Masyarakat Desa}

Tanggapan responden, terkait pertanyaan tentang radio desa apakah mempengaruhi opini dan partisipasi masyarakat. Mayoritas yakni 63 persen responden menyatakan informasi yang diberikan oleh radio desa (setuju) mempengaruhi opini dan partisipasi masyarakat. Hanya 34 prosen yang 
menyatakan tidak berpengaruh. Oleh karena itu, maka program yang ada di RadioDesa dapat disesuaikan dengan kebutuhan pemerintah dan masyarakat dalam pembangunan desa.

\subsubsection{Indikator Radio Desa Sebagai Komunikasi Massa Mampu Meningkatkan Partisipasi Masyarakat Dalam Bidang Pembangunan}

Tanggapan responden, terkait pertanyaan tentang radio desa mampu meningkatkan partisipasi masyarakat dalam bidang pembangunan. Mayoritas yakni 63 persen responden menyatakan Radio desa mampu meningkatkan partisipasi masyarakat dalam bidang pembangunan. Hanya 34 prosen yang menyatakan tidak berpengaruh. Oleh karena itu, maka program yang ada di Radio Desa perlu dioptimalkan.

\subsubsection{Indikator Radio Desa Sebagai Komunikasi Massa Mampu Meningkatkan Partisipasi Masyarakat Dalam Bidang Sosial}

Berdasarkan radio hasil penelitian, hampir sama pada pembahasan sebelumnya pada garafik 4.13 bahwa mayoritas yakni 63 persen responden menyatakan Radio desa mampu meningkatkan partisipasi masyarakat dalam bidang sosial, seperti kegiatan gotong royong. Hanya 34 prosen yang menyatakan tidak berpengaruh. Oleh karena nampaknya, Radio desa mampu meningkatkan partisipasi masyarakat dalam bidang sosial di Desa Sempu, oleh karena itu Radio Desa ke depandapat mampu mendukung partsispasi, pembangunan di Desa Sempu. 


\section{PENUTUP}

Berdasarkan hasil analisa data dan pembahasan, dapat disimpulkan bahwa Radio Desa yang ada di Desa Sempu memiliki hubungan terhadap partisipasi masyarakat dalam kegiatan desa, hal tersebut disebabkan oleh karena radio desa dipersepsikan positif, baik secara informasikan yang diberikan oleh Radio Desa dan acara yang disuguhkan oleh radio desa sesuai dengan kebutuhan masyarakat dan berdampak pada partisipasi masyarakat desa, sehingga Radio Desa sudah memerankan diri sebagai komunikasi massa, hal tersebut terbukti dari 7 varibel pertanyaan, dan 7 pertanyaan terkait dengan partisipasi masyarakat desa. selanjutnya berdasarkan mayoritas jawaban responden terhadap semua pertanyaan memberikan penjelasan bahwa keberadaan Radio Desa memiliki dampak atau hubungan signifikan terhadap peningkatan partisipasi masyarakat di Desa Sempu. 


\section{DAFTAR PUSTAKA}

Alam Setia Zain, 1998, Komunikasi Massa, Rieneka Cipta, Jakarta.

Bambang Pamulardi, 1995, Radio Komunitas Sebagai Sarana Informasi, Raja Grafindo Persada, Jakarta.

Deddy K, Partisipasi Publik dalam Pembangunan, Makalah, Direktorat Pengembangan Otonomi Daerah.

Effendi Unong Uchjana, 1992: Dimensi - dimensi Komunikasi tujuan komunikasi

Erlangga Agustino Landiyanto, Desa dan Pemerintahan Desa Sebagai Entitas Publik, Cures Working Paper 05/01, Januari 2005. 